\title{
PENGARUH LATIHAN PEREGANGAN TERHADAP FLEKSIBILITAS LANSIA
}

\author{
${ }^{1}$ Renold C. Ibrahim \\ ${ }^{2}$ Hedison Polii \\ ${ }^{2}$ Herlina Wungouw
}

\author{
${ }^{1}$ Kandidat Skripsi Fakultas Kedokteran Universitas Sam Ratulangi Manado \\ ${ }^{2}$ Bagian Fisiologi Fakultas Kedokteran Universitas Sam Ratulangi Manado \\ Email: renoldcristian@ysahoo.com
}

\begin{abstract}
Flexibilityis the ability of a joint, muscles, and ligaments around it to move free lyandcomfortably in the space for the expected maximum. Flexibility is influenced by many factors. These factors are the muscles, tendons, ligaments, age, gender, body temperature and joint structure. Less flexibility may lead toa slower movement and injury pronetomuscles, ligaments, andothertissues. With increasing age, the person's flexibility will reduce. The best way to increase the flexibility is stretching exercises. This study aimed to find the effect of stretching exercises for flexibility among the eldery. This was an experimental field study with pre-post test design. Samples were 30 elderly people who were in BPLU Senjah Cerah, Paniki Bawah. Samples were measured by using a goniometer flexibility before doing stretching exercises. After stretching exercises for 3 weeks, they were measured again with the goniometer. The results showed that stretching influenced the flexibility of the elderly $(p<0.05)$, except the glexibility of the right arm flexion did not increase $p=0.134(p>0.05)$. Conclusion: Stretching exercises can improve joint flexibility.
\end{abstract}

Keywords: flexibility, stretching exercises, elderly

\begin{abstract}
Abstrak: Fleksibilitas merupakan kemampuan dari sebuah sendi,otot dan ligamen di sekitarnya untuk bergerak dengan leluasa dan nyaman dalam ruang gerak maksimal yang diharapkan. Fleksibiltas dipengaruhi oleh banyak factor yaitu otot, tendon, ligamen, usia, jenis kelamin, suhu tubuh dan struktur sendi. Fleksibilitas yang kurang dapat menyebabkan gerakan lebih lamban dan rentan terhadap cedera otot, ligamen, dan jaringan lainnya. Dengan bertambahnya usia maka fleksibilitas seseorang akan berkurang. Cara terbaik meningkatkan fleksibilitas ialah dengan latihan peregangan. Penelitian ini bertujuan untuk melihat pengaruh latihan peregangan terhadap fleksibilitas. Penelitian ini bersifat eksperimental lapangan dengan rancangan pre-post test design. Sampel berjumlah 30 orang Lansia yang berada di BPLU Senjah Cerah, Paniki Bawah. Sampel di ukur fleksibilitasnya dengan menggunakan goniometer terlebih dahulu sebelum melakukan latihan peregangan Setelah latihan peregangan selama 3 minggu dilakukan pengukuran kembali dengan menggunakan goniometer. Hasil yang didapatkan terdapat pengaruh peregangan lingkup gerak sendi pada fleksibilitas lansia $(\mathrm{p}<0,05)$ kecuali pada fleksi lengan dextra tidak terjadi peningkatan fleksibilitas diperoleh nilai $\mathrm{p}=0,134(\mathrm{p}>005)$. Simpulan: Latihan Peregangan dapat meningkatkan Fleksibilitas Sendi.
\end{abstract}

Kata kunci: fleksibilitas, latihan peregangan, lansia

Penuaan adalah suatu proses menghilangnya secara perlahan-lahan kemampuan jaringan untuk memperbaiki diri atau mengganti dan mempertahankan fungsi normalnya sehingga tidak dapat bertahan terhadap infeksi dan memperbaiki 
kerusakan yang diderita. Proses menua merupakan proses yang terus-menerus berlanjut secara alamiah dimulai sejak lahir dan dialami oleh semua mahkuk hidup. Lanjut usia menurut Undang-Undang Nomor 13 tahun 1998 adalah mereka yang telah memasuki usia 60 tahun ke atas. Diseluruh dunia penduduk lansia (usia 60 tahun ke atas) tumbuh sangat cepat bahkan tercepat dibandingkan kelompok usia lainnya. Badan kesehatan dunia WHO menunjukan bahwa presentase penduduk lanjut usia akan mencapai 9,77 persen dari total penduduk pada tahun 2010 dan menjadi 11,34 persen pada tahun $2020 .^{1}$

Lanjut usia sering dikaitakan dengan usia yang sudah tidak produktif, bahkan dikatakan menjadi beban bagi yang berusia produktif. Hal ini terjadi karena pada lansia secara fisiologis mengalami kemunduran fungsi-fungsi dalam tubuh yang menyebabkan lansia rentan terkena gangguan kesehatan. Memasuki lanjut usia akan mengalami kemunduran secara fisik, kemunduran secara fisik akan terjadi penurunan massa otot serta fleksibilitasnya. Sehingga, dapat mempengaruhi kemampuan lansia dalam memenuhi aktivitasnya. Kemunduran secara fisik akibat proses penuaan dapat dicegah pada lansia dengan melakukan berbagai komponen latihan. Komponen latihan pada lansia dapat diberikan dengan latihan fleksibilitas. $^{2}$

Fleksibilitas dapat didefinisikan sebagai kemampuan dari sebuah sendi dan otot, serta tali sendi di sekitarnya untuk bergerak dengan leluasa dan nyaman dalam ruang gerak maksimal yang diharapkan.Fleksibiltas dipengaruhi oleh banyak faktor. Faktor-faktor tersebut adalah otot, tendon, ligamen, usia, jenis kelamin, suhu tubuh dan struktur sendi. Fleksibilitas yang kurang dapat menyebabkan gerakan lebih lamban dan rentan terhadapa cedera otot, ligamen, dan jaringan lainnya. Dengan bertambahnya usia maka fleksibilitas seseorang akan berkurang. Cara terbaik meningkatkan fleksibilitas adalah dengan latihan peregangan. $^{3}$
Latihan peregangan penting untuk mencegah kemunduran massa otot. Latihan-latihan itu dibagi atas dua jenis latihan yaitu latihan peregangan statis dan latihan peregangan dinamis. Dengan melakukan kedua latihan ini maka dapat meningkatkan fleksibilitas. ${ }^{4}$

Berdasarkan pembahasan diatas penulis tertarik untuk meneliti latihan peregangan terhadap fleksibilitas lansia.

\section{METODE PENELITIAN}

Metode penelitian ini merupakan penelitian eksperimental dengan rancangan pre-post one group test. Penelitian dilakukan di Balai Penyantunan Lanjut Usia (BPLU) Senja Cerah Manado. Waktu penelitian selama Oktober 2014 sampai Januari 2015.

Populasi penelitian adalah lansia di BPLU Senja Cerah. Sampel penelitian merupakan populasi lansia yang memenuhi kriteria inklusi. Kriteria inklusi pada penelitian ini berusia di atas 60 tahun dan bersedia menjadi responden dan mengisi informed consent sedangkan kriteria eksklusi yaitu sakit sendi. Variabel bebas penelitian yaitu latihan peregangan dan variabel terikat yaitu fleksibilitas

Lansia adalah orang yang berusia di atas 60 tahun. Proses latihan yang dilakukan secara teratur, berulang pada orang yang berusia di atas 60 tahun dengan melakukan latihan peregangan. Fleksibilitas diukur dengan menggunakan goniometer.

Latihan peregangan dilakukan 1 kali 1 hari tiap bangun tidur selama 3 minggu. Sebelum melakukan latihan peregangan lansia diukur terlebih dahulu lingkup gerak sendi dengan menggunakan Goniometer. Latihan ini berupa lima gerakan latihan yaitu, fleksi lengan sinistra, fleksi lengan dextra, ekstensi lengan sinistra, ekstensi lengan dextra, fleksi bahu sinistra, fleksi bahu dextra, ekstensi bahu sinistra, ekstensi bahu dextra, abduksi bahu sinistra dan abduksi bahu dextra, fleksi lutut sinistra, fleksi lutut dextra, ekstensi lutut sinista dan ekstensi lutut dextra. latihan peregangan di pakai 2 metode yaitu, metode dinamis dan 
statis. Metode dinamis dilakukan dengan menggerakan anggota tubuh secara berulangkali tapi teratur dan metode statis dilakukan dengan meregangkan otot secara perlahan-lahan dengan menahan 20-30 detik. 3 minggu kemudian, responden dikumpulkan untuk dilakukan pengukuran fleksibilitas sebagai post test dengan metode yang sama

Data dianalisis dengan uji $\mathrm{T}$ berpasangan untuk mengetahui ada tidaknya perbedaan antara fleksibilitas sendi sebelum dan sesudah latihan beban pada lansia. Uji statistik dijalankan dengan menggunakan perangkat lunak SPSS (Statistical Product and Service Solutions) versi 20.0.

\section{HASIL PENELITIAN}

Penelitian ini bersifat eksperimental lapangan dengan rancangan pre post design yang dilakukan sejak bulan November 2014 sampai bulan Januari 2015 di BPLU Senja Cerah Paniki bawah, pada awal penelitian terlebih dahulu meminta izin kepada kepala BPLU untuk melakukan penelitian dengan membawa surat izin penelitian yang dikeluarkan dari bagian Fisiologi Fakultas Kedokteran Universitas Sam Ratulangi. Setelah mendapatkan izin, peneliti melakukan sosialisasi kepada lansia yang berada di BPLU Senja Cerah.

Pada penelitian ini, peneliti mengambil 30 orang lansia yang sesuai dengan kriteria inklusi dari jumlah 40 orang lansia yang tinggal di BPLU. Sebelum dilakukan penelitian 30 orang lansia telah mengisi informed consent, setelah itu dilakukan pengukuran lingkup gerak sendi (LGS) terlebih dahulu sebelum melakukan latihan peregangan. Hasil analisis data secara univariat menjelaskan tentang distribusi frekuensi responden berdasarkan jenis kelamin dan umur responden. Berdasarkan analisis data deskriptif, dari 30 responden penelitian telah diperoleh data jenis kelamin seperti gambar berikut.

Berdasarkan Gambar 1 dapat dilihat bahwa sebagian besar responden lansia yang diambil adalah berjenis kelamin perempuan dengan jumlah 18 responden
(60\%) dan laki-laki berjumlah 12 responden (40\%).

\section{Jenis Kelamin}

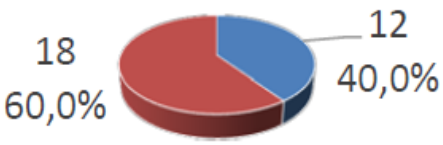

- Laki-laki - Perempuan

Gambar 1. Grafik Distribusi Responden menurut Jenis Kelamin

Berdasarkan Gambar 2 dapat dilihat bahwa sebagian besar responden lansia yang diambil adalah mempunyai golongan umur 75-90 tahun dengan jumlah 17 responden $(56,7 \%)$ dan golongan umur 60 74 tahun berjumlah 13 responden (43,3\%).

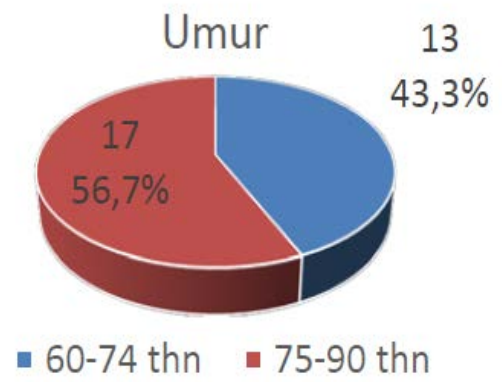

Gambar 2. Grafik Distribusi Responden menurut Umur

Berdasarkan Gambar 3 dapat dilihat perbandingan nilai fleksibilitas lengan pada lansia, dimana sebelum dilakukan latihan peregangan nilai fleksibilitas fleksi lengan sinistra adalah 38,20 , setelah dilakukan latihan peregangan menjadi 39,13. Nilai fleksibilitas fleksi lengan dextra sebelum latihan peregangan adalah 38,56, setelah dilakukan latihan peregangan menjadi 38,73. Nilai fleksibilitas ekstensi lengan sinistra sebelum peregangan adalah 178,36, setelah dilakukan latihan peregangan menjadi 179,36. Nilai fleksibilitas ekstensi lengan dextra sebelum peregangan adalah 178,33, setelah dilakukan latihan peregangan menjadi 179,33. 


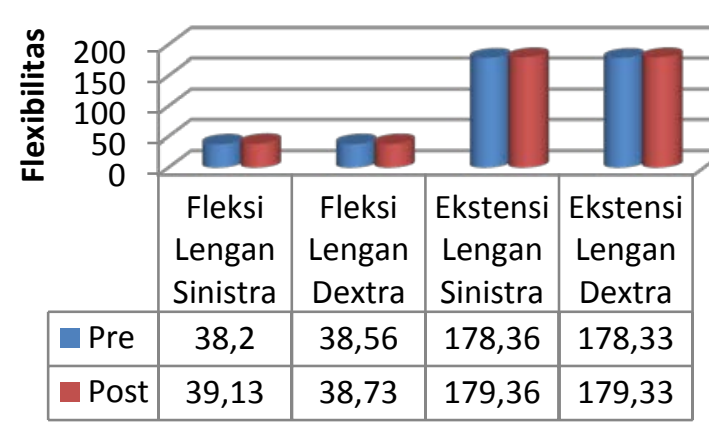

Gambar 3. Grafik Perbandingan Nilai RataRata Fleksibilitas pada Lengan

Berdasarkan Gambar 4 dapat dilihat perbandingan nilai fleksibilitas bahu pada lansia, dimana sebelum dilakukan latihan peregangan nilai fleksibilitas fleksi bahu sinistra adalah 178,36, setelah dilakukan latihan peregangan menjadi 179,36 . Nilai fleksibilitas fleksi bahu dextra sebelum latihan peregangan adalah 178,40, setelah dilakukan latihan peregangan menjadi 179,26. Nilai fleksibilitas ekstensi bahu sinistra sebelum peregangan adalah 91,83, setelah dilakukan latihan peregangan menjadi 58,00. Nilai fleksibilitas ekstensi bahu dextra sebelum peregangan adalah 91,66, setelah dilakukan latihan peregangan menjadi 58,20.

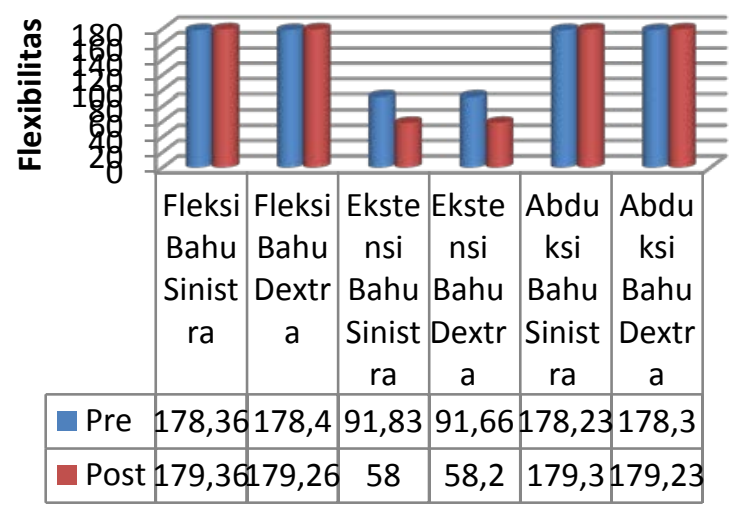

Gambar 4. Grafik Perbandingan Nilai RataRata Fleksibilitas pada Bahu

Nilai fleksibilitas abduksi bahu sinistra sebelum peregangan adalah 178,23 , setelah dilakukan latihan peregangan menjadi 179,30. Nilai fleksibilitas abduksi bahu dextra sebelum peregangan adalah 178,30, setelah dilakukan latihan peregangan menjadi 179,23.
Berdasarkan Gambar 5 dapat dilihat perbandingan nilai fleksibilitas lutut pada lansia, dimana sebelum dilakukan latihan peregangan nilai fleksibilitas fleksi lutut sinistra adalah 132,53, setelah dilakukan latihan peregangan menjadi 133,33 . Nilai fleksibilitas fleksi lutut dextra sebelum latihan peregangan adalah 132,53 , setelah dilakukan latihan peregangan menjadi 133,43. Nilai fleksibilitas ekstensi lutut sinistra sebelum peregangan adalah 178,23, setelah dilakukan latihan peregangan menjadi 179,36. Nilai fleksibilitas ekstensi lutut dextra sebelum peregangan adalah 178,30, setelah dilakukan latihan peregangan menjadi 179,26.

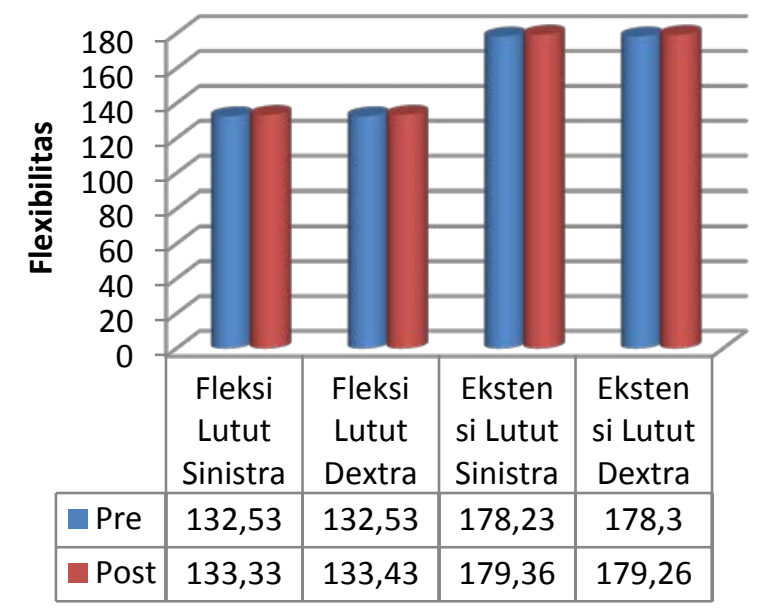

Gambar 5. Grafik Perbandingan Nilai RataRata Fleksibilitas pada Lutut

\section{BAHASAN}

Hasil karakteristik univariat menunjukkan bahwa sebagian besar responden lansia adalah perempuan sebanyak 18 responden (60\%) dan laki-laki sebanyak 12 responden (40\%). Sedangkan dari segi umur, berdasarkan kategori lansia menurut World Health Organization, rentang umur 60-74 tahun yaitu termasuk dalam golongan lanjut usia berjumlah 13 responden $(43,3 \%)$ dan rentang umur $>75$ tahun yaitu termasuk golongan lanjut usia tua sebanyak 17 responden (56,7\%). Pada lanjut usia akan terjadi proses menghilangnya kemampuan jaringan untuk memperbaiki diri atau mengganti dan 
mempertahankan fungsi normalnya secara perlahan-lahan sehingga tidak dapat bertahan terhadap infeksi dan memperbaiki kerusakan yang terjadi.

Analisis statistikdigunakan untuk melihatpengaruh latihan peregangan terhadap fleksibilitas lansia berdasarkan pengukuran lingkup gerak sendi (LGS). Berdasarkan hasil analisis statistik menggunakan Wilcoxon Signed Ranks, terdapat pengaruh peregangan pada beberapa lingkup gerak sendi pada lansia di BPLU Senja Cerah Manado. Lingkup gerak sendi yang ada pengaruhnya adalah pada fleksi lengan sinistra, fleksi lengan dextra, ekstensi lengan sinistra, ekstensi lengan sinistra, ekstensi lengan dextra, fleksi bahu sinistra, fleksi bahu dextra, ekstensi bahu sinistra, ekstensi bahu dextra, abduksi bahu sinistra dan abduksi bahu dextra, fleksi lutut sinistra, fleksi lutut dextra. Sedangkan lingkup gerak sendi yang tidak ada pengaruh peregangan adalah pada ekstensi lutut sinistra dan ekstensi lutut dextra.

Hasil tersebut menunjukkan bahwa kecuali pada ekstensi lutut sinistra dan ekstensi lutut dextra ( $p>0,05)$, semua lingkup gerak sendi ternyata fleksibilitas pada lansia dapat dipengaruhi oleh peregangan $(p<0,05)$. Latihan fleksibilitas adalah aktivitas untuk membantu mempertahankan kisaran gerak sendi, yang diperlukan untuk melakukan aktivitas fisik dan tugas sehari-hari secara teratur. Latihan fleksibilitas dianjurkan dilakukan 1 hari 1 kali selama 3 minggu hari pada saat bangun tidur. Latihan dengan melibatkan peregangan otot dan sendi. Intensitas latihan dilakukan dengan memperhatikan rasa tidak nyaman atau nyeri. Peregangan dilakukan 1-2 kali,untuk masing-masing gerakan dipertahankan 10-30 detik. Peregangan dilakukan terutama pada kelompok otot-otot besar, dimulai dari otototot kecil. Dari hasil penelitian yang dilakukan pada lansia di BPLU Senja Cerah Manado sebelum dan setelah peregangan dapat dilihat perkembangan fleksibilitas dengan menggunakan goniometer.

Kesoema dalam penelitiannya menyatakan bahwa terdapat peningkatan kemampuan kontraksi maksimal otot dasar panggul pada wanita lansia. Dalam penelitiannya menyatakan bahwa terdapat pengaruh senam lansia terhadap kemampuan fungsional pada lansia yang mengalami nyeri punggung. Berbagai latihan sebisa mungkin dilakukan pada lansia dengan memperhatikan faktor keamanan pada lansia. Hal ini dilakukan dalam upaya meningkatkan efektifitas anggota gerak badan pada lansia. ${ }^{5}$

Pemaron menyatakan ada pengaruh peregangan statis dan dinamis terhadap perubahan intensitas nyeri sendi lutut pada lansia dengan osteoarthritis.Sendi lutut merupakan struktur tulang dari tungkai atas dan tungkai bawah yaitu tulang femur, tibia, fibula dan patella serta dibentuk dari beberapa ligamen dan minikus. Sendi lutut mempunyai gerakan diantaranya fleksi, ekstensi, eksternal rotasi. Gerakan fleksi dari posisi full ekstensi, dimulai gerakan rotasi secara simultan tibia terhadap femur melalui kontraksi otot popliteus, selanjutnya terjadi gerakan fleksi aktiv akibat kontraksi m. Hamstring. Pada gerakan fleksi-ekstensi maka meniscus akan menguat terhadap tibia yang bergerak terhadap femur. Pada gerakan rotasi dengan fleksi lutut, maka meniscus akan bergerak mengikuti femur terhadap tibia. Ligamentum cruciatum anterior akan mengalami penegangan saat ekstensi dan mengendor saat fleksi. Gerakan rotasi eksternal tibia terhadap femur pada 20 derajat menuju posisi ekstensi disebut mekanisme screw home dan keaadan tersebut dipengaruhi susunan kondilus dan pengendalian struktur ligamentosa. Ligamentum yang berhubungan dengan kapsula sendi akan tertarik kearah anterior dan keatas, sehinggga mencegah terjadinya pergerakan antara condylus pada sisi yang berlawanan. ${ }^{6}$

Ada tiga facet sendi pada permukaan persendian dari femur. Pada pergerakan menuju fleksi menuju ekstensi, maka hubungan antara permukaan sendi melalui dari facet medial dan selanjutnya kefacet interior. Kerja otot pada pergerakan 
ekstensi dilakukan oleh kelompok otot biceps femoris. Struktur ligamen akan membantu ekstensi lutut ketika tibia menguat pada posisi menumpu berat badan. Saat lutut bergerak dari fleksi ke ekstensi, gerakan kondylus lateral akan dihentikan pada gerak sendi 160 derajat oleh ligamen cruciatum anterior dan ligamentum colateralis. Kontraksi m. quadriceps menyebabkan kondylus medialis akan menambah jangkauan jarak gerak sendi sebesar 20 derajat (untuk menambah full fleksi menjadi 180 derajat) dan menimbulkan gerakan internal rotasi tibia terhadap femur.

\section{SIMPULAN}

Berdasarkan hasil penelitian dapat disimpulkan bahwa terdapat pengaruh peregangan lingkup gerak sendi pada fleksibilitas lansia kecuali pada fleksi lengan dextra tidak terdapat pengaruh.

\section{DAFTAR PUSTAKA}

1. Azizah M, Lilik. Keperawatan Lanjut Usia. Yogyakarta. Graha Ilmu. 2011. p.1-10

2. Padila. Buku Ajar Keperawatan Gerontik. Yogyakarta. Medical Book. 2013. p.4-6 ; 89-90

3. Badan Pusat Statistik. Statistik Penduduk Lanjut Usia 2009. Jakarta: Badan Pusat Statistik; 2009.

4. Susanto, Rudy. Meningkatkan fleksibilitas tubuh dengan gerakan sederhana.2013. Avaible From: http://www.indotopinfo.com/meningkat kan-fleksibilitas-tubuh.html

5. Paramihta $\mathbf{P}$. Latihan peregangan statis dan dinamis terhadap perubahan intensitas sendi lutut pada lansia.2014.vol 2, p.3

6. Kesoema,Tanti A. Perbandingan hasil aplikasi tens dan latihan volunteer terhadap kemampuan dan durasi kontraksi maksimal otot dasar panggul pada wanita lansia.2004. Master thesis, Program Pascasarjana Universitas Diponegoro. 